TADEUSZ TABACZNIUK

\title{
Management of public safety with the use of visual monitoring in the city and county of Walbrzych
}

Tadeusz Tabaczniuk, Ph.D. University of Zielona Góra, Faculty of Economics and Management

\section{Introduction}

The safety of local communities, and each member of the community in the borders, is a core value not subject to discussion. The appropriate level of security is a guarantee of stability, development and progress. The level of public safety is affected by any violation of social norms, violence, regardless of where, aggressive behaviour. Lack of security and public order and crime threat, resulting from such a state, the fear of becoming a victim of crime, or social pathologies are often the main problems of modern cities, regardless of their size (Sienkiewicz-Małyjurek 2010, p.222). The development of information technology has enabled the introduction of modern technology to a public space supporting specialist services responsible for security and public order in the performance of their tasks. One of such techniques is visual monitoring. This paper is an attempt to determine the real impact of the use of video monitoring by authorized professionals - on the number of new cases initiated on the basis of crime threat index to the selected area. It should also be added that it is a continuation of earlier research conducted in this field by the author. 


\section{Legal aspects related to the operation of video monitoring in Poland}

The beginning of the 90s of the last century in Poland initiated the development of many areas of life, which previously could be only learned from films or books. With the big system changes, the changes in the Polish mentality were taking place. The difficulties caused by the lower standard of living in Poland than in the EU states did not prevent intense development of many aspects of everyday life. But the wind of change did not concern only the positive sides of life. Almost all the negative aspects of the "western lifestyle" were similarly transferred to the native land - there was a rapid growth of multiple threats, including - related to safety and order in public spaces. As natural happened countering emerging threats: both in the legal and organizational - technical sphere. One such a solution was the introduction, and in later years - rapid development, mainly quantitative - of video monitoring systems. One of the main features of a democratic system is that it provides its citizens with rights. The state should provide safety to all citizens within the framework of these rights. But democracy is also a legal system, in which everything should be clearly defined. Thus, a question arises: are there in Poland legal standards, which clearly defined regulations relating to visual monitoring of public space? The answer is simple. There is not still developed a comprehensive legislative framework for the operation of video monitoring. This is translated into a lack of clear rules for the use of monitoring and guarantee to protect the privacy of individuals whose behaviour is observed or recorded (Skórzyńska-Ślusarek 2013 , p.2). The problem of the functioning of video monitoring systems was partially regulated in different laws, which could include, among others:

- act on the Police (Journal of Laws of 2007 no. 43, item. 277, as amended),

- act on the protection of persons and property (Journal of Laws of 1997.114.740 as amended),

- act on the safety of mass events (Journal of Laws of 2009.62. 504, as amended),

- act on crisis management (Journal of Laws of 2007.89.590, as amended),

- act on commune guards (Journal of Laws of 1997.123 .779 as amended),

- act on the protection of personal data (Journal of Laws of1997.133. 883, as amended),

- code of criminal procedure act (Journal of Laws of 1997.89.555 as amended),

- executive penal code act (Journal of Laws of 1997.90.557, as amended),

- act on gambling (Journal of Laws of 2009.201.1540, as amended).

A series of implementing regulations has been issued to the above-mentioned laws and separately. However, just as in the laws, there is no comprehensive 
approach to issues related to video monitoring. There is a slight difference with the legal status associated with the technical requirements regarding video monitoring. After joining the European Union - Polish standards in this area - were adapted to the requirements of the EU. Technical requirements were specified in detail associated with analogue video monitoring. It is described in PN-EN 50132:2003 Alarm systems - CCTV surveillance systems used in security applications.

However, there are still vague requirements for the construction and use of digital CCTV systems. The dynamic growth of users of digital CCTV system so far has not affected the emergence of standards, which would define the overall requirements and regulations concerning the construction of this type of installation. The intermediate output from the existing lack of legal solutions is the use of standards for analogue CCTV systems, in the construction of digital CCTV systems, containing general requirements for this type of security systems and standards relating to the construction of computer networks, TCP / IP (http://www.ip.pl/ pomoc/przeglad-norm-dotyczacych-budowy-systemowcctv-ip.htm,2016).

The problem of the lack of a comprehensive law on video monitoring has been discussed over the years. Not having the appropriate legal solutions is a serious shortcoming, because, according to existing case law, monitoring systems used almost anywhere in an open public space can be regarded as the processing of personal data. A lack of specific regulations could involve use of the provisions of the act on the protection of personal data. The consequence of this situation is the need not only to inform about the monitoring, but also the registration of data sets in GIODO. It does not apply only to the cameras that are used to register live, and from which the image is not recorded. There is no collection of personal data - there is no need to register in GIODO (Wikariak 2014).

\section{Management of visual monitoring systems}

Video monitoring is very often the only and therefore almost invaluable source of information about events that require the intervention of various services and institutions responsible for security and public order. In a wellrunning system, the picture of events captured by camera initiates or supports the activities of the municipal guards, police, ambulance or fire brigade (http:// www.strazmiejskajaslo.pl 2016). It can also be used for legal purposes. However, to make it possible, it should be normalized with appropriate legal action at the level of cities and municipalities. Therefore, the development of comprehensive 
solutions by some of the city/municipalities, which define the coordinated actions aimed at improving the situation in this field, should be considered as an appropriate operation. The implementation of such programs often determines the need to build and further use of video monitoring systems. However, a decisive condition for conducting a city monitoring system by municipal guards, resulting from the act on commune guards (Journal of Laws of 1997.123.779 as amended) art. 11 paragraph 2, is the necessity to perform the tasks of the guards. Therefore, it is necessary to determine in the planning stage of monitoring system (NIK Report, 2013, p.11):

- problems related to security and crime prevention in a specific area to justify the construction of the system,

- needs as a basis for defining the objectives of monitoring,

- methods of action, recognizing monitoring system for part of coordinated action aimed at protecting the safety,

- ensuring the effective functioning of the municipal system of monitoring through a system of surveillance, used to detect and eliminate irregularities in its operation.

After determining planning assumptions, it is possible to expect a number of benefits from the use of video monitoring in three basic functions (SienkiewiczMałyjurek 2010, p. 224):

- preventive function - to deter potential perpetrators of offenses and crimes in the area of security and public order,

- evidence function - a registered picture of events can constitute evidence of the trial,

- operating function - supporting the activities of services, inspections, guards responsible for security and public order, improving coordination and course of action.

The above sequence is random, because it depends in turn on ways of operating systems installed. A different one will be while using the monitoring operator when the display of video on a regular basis is subjected to "processing". Another when the recorded image will only be temporarily or permanently browsed e.g. every 24 hours or other interval. In the literature it is possible to find a lot of video monitoring systems used in public spaces. However, generally we distinguish the following ones:

1. Reactive system_- acting when recording images from fixed cameras and/or rotating ones, moving at the programmed time and the programmed tracks. The effectiveness of such a solution is very low, random.

2. Active system_- acting just like reactive. The difference is that the duty of 
police/municipal police, after receiving a phone application checks whether the reported event is/was in the field of view of the camera. If so, they pass the information to patrol and can follow the course of events. However, the effectiveness of such a solution in the literature is also assessed as very low.

3. Proactive system_- supervised areas are observed by trained operators continuously, without interruption. As a result, based on the analysis of behaviour, body language of people being observed, it is possible to predict dangerous ones and quickly inform the duty of the police or municipal guards about the situation/event. Coordinated action by the police, municipal guards and other law enforcement officials as soon as possible allows reaching the patrol to the scene and preventing or minimizing the risk of losses. The leading role in the pro-active systems is played by the operator who, tracking the event, guiding accordingly cameras, can significantly support the work of the intervening officers on duty by informing the relevant departments. Moreover, automatically, the incident, patrol operation etc. is recorded. The effectiveness of this type of system is high.

Such capabilities can be implemented provided there is the appropriate focus operator/team of operators (the number of operators should be dependent solely on the number of cameras of the monitoring system) for constant observation and responding to situations carrying a threat to human life and health and property located in the area of supervision of cameras (http://www.strazmiejskajaslo.pl 2016). In the literature on the effectiveness of the functioning of the monitoring systems it is emphasized that the permitted number of images from the cameras monitored by one operator should not exceed 16. The studies cited by The Home Office Scientific Development Branch (HOSDB) - scientific research unit of the British Ministry of Internal Affairs (Tickner and Polton ) indicate that the effectiveness of monitoring operators to detect a person in the crowded centre of the city is for four monitors $93 \%$, for $9-84 \%$, for $16-64 \%$ (report of the Supreme Chamber of Control 2013, p. 14).

The fulfilment of these objectives, functions, selection of the type of video system or selection of system operators can fully utilize the capabilities of video monitoring applications.

\section{The evolution of monitoring systems in the city and county of Walbrzych}

The study has covered the city and county of Walbrzych. One of the conditions of installation and subsequent expansion of video monitoring systems is the level of social acceptance and public feedback on their performance. As a rule, 
the existence of systems is seen positively by the local community. For example, the results of research carried out in this area in Silesia province show that about $85 \%$ of local communities accepted the functioning of such systems (SienkiewiczMałyjurek, Niczyporuk 2010, p. 94).

In previous studies conducted five years earlier, the initial area of research was also similar to the present one, but over time it was narrowed only to the city, because in the rural district video monitoring was conducted virtually residually. With time, monitoring systems began to be installed in following municipalities. However, not all municipalities went in the direction of complete solutions, i.e. monitoring systems. A part started its activity in the sphere of security with object installations - usually on public buildings - schools, libraries, cultural centres. However, this type of monitoring does not create a coherent network, or system, and the information obtained is reactive. The detailed data related to the quantity and types of video monitoring are shown in Table 1. In Walbrzych the emergence and development of the visual monitoring system was initiated in 2002. In the first phase of development of the system it consisted of only 10 cameras and a monitoring service station located at the police station. Its range covered the very centre of the city. In 2010, there was a development of the system - up to 18 cameras. There was established a separate control centre allowing all day, continuous monitoring and a quick response to arising situations. It was planned, in the near future, a further expansion of the system, especially in large residential areas, where there is a problem of vandalism and hooliganism (Gołębiowski 2010, p. 4).

Table 1. Characteristics of the amounts and types of monitoring in the studied area

\begin{tabular}{l|c|c}
\hline Name of city/municipality & $\begin{array}{c}\text { Type } \\
\text { of monitoring }\end{array}$ & Number of cameras \\
\hline Walbrzych - city & Proactive & 36 \\
\hline Szczawno Zdroj (municipality) & Reactive & 8 \\
\hline Jedlina - Zdroj (municipality) & Reactive & 5 \\
\hline Boguszów - Gorce (municipality) & Reactive & 8 \\
\hline Walim (rural) & Reactive & - \\
\hline Gluszyca (urban - rural) & None & \\
\hline$-\cdots$
\end{tabular}




\begin{tabular}{l|c|c} 
Mieroszow (urban - rural) & None & $\begin{array}{c}\text { it is "residual”, i.e. single cameras on } \\
\text { the premises and so-called „camera } \\
\text { - trap" }\end{array}$ \\
\hline Czarny Bor (rural) & Object & team schools, cultural centre \\
\hline Stare Bogaczowice (rural) & Object & team schools, library \\
\hline
\end{tabular}

Source: own study

In July 2011, following the reorganization of the district and municipal structures - Municipal Guards in Walbrzych received a duty to operate video monitoring. Consequently - in March 2012 the position of monitoring supervision was transferred to the headquarters of the Municipal Guards (Video monitoring of Walbrzych 2016). Currently this position employs four skilled operators working in shifts. As observed during the on-call events, depending on qualifications - they are passed through separate channels of communication to the control position of Municipal Police or the Municipal Guards patrol. Another extension of the system was made in 2013 (11 cameras) and the last in 2014-2015 (10 cameras). From 1 January 2016, the monitoring system includes 46 cameras working in a CCTV system - covering almost the entire district of the city - Downtown. In the nearest future it is planned to expand further the visual monitoring system by 30 cameras (List of cameras, 2015 pp. 1-2).

In 2012-2014 in Szczawno Zdroj video monitoring CCTV system was extended for EU funds, currently made up of 32 cameras connected with the position of the operator through fibre, coaxial or radio links. The concept of the system was adopted in a reactive form, i.e. the information obtained is stored on the media. The overview of the collection of information is carried out on an ad hoc basis depending on the time of the municipal guards or of the events. Practically, the obtained information is used solely for the trial purposes or for the purposes of investigations conducted by the police or municipal guards.

Another municipality, which in recent years installed video monitoring system CCTV is Jedlina Zdroj. This is a typical reactive system consisting of 8 cameras and the service station located in the Commune Office. Cameras of the system are arranged in selected by the municipal authorities public places. The recordings are stored for about 2 weeks, then the next overwrite follows. It is used only for the purposes of investigations conducted by the police or for the trial.

The last place of the Walbrzych county, where video monitoring system functions, is Boguszów-Gorce. It is also a reactive system consisting of 5 cameras 
and the service station located in a room of the Municipal Guards. It was built in 2008-2009 and since then not subject to the modernization and expansion. Its range of surveillance includes the observation centre of Boguszów - immediate surroundings of the Municipal Council.

\section{The crime rate as a measure of public safety}

Due to the fact that the use by the author of the statistical data compiled in different countries, where the sets of criminal offenses and punishable are recognized differently in the statistics of police and prosecutors the following respective risk indicators are estimates.

In order to assess the ability of the main actors responsible (Police, Municipal Guards) to ensure security and public order in the city and county of Walbrzych, an analysis of data was carried out relating to offenses recorded by the police in the area and in Poland, selected countries of the European Union (EU). Simple data on crime in the studied area was combined, then converted to rates per 1000 inhabitants.

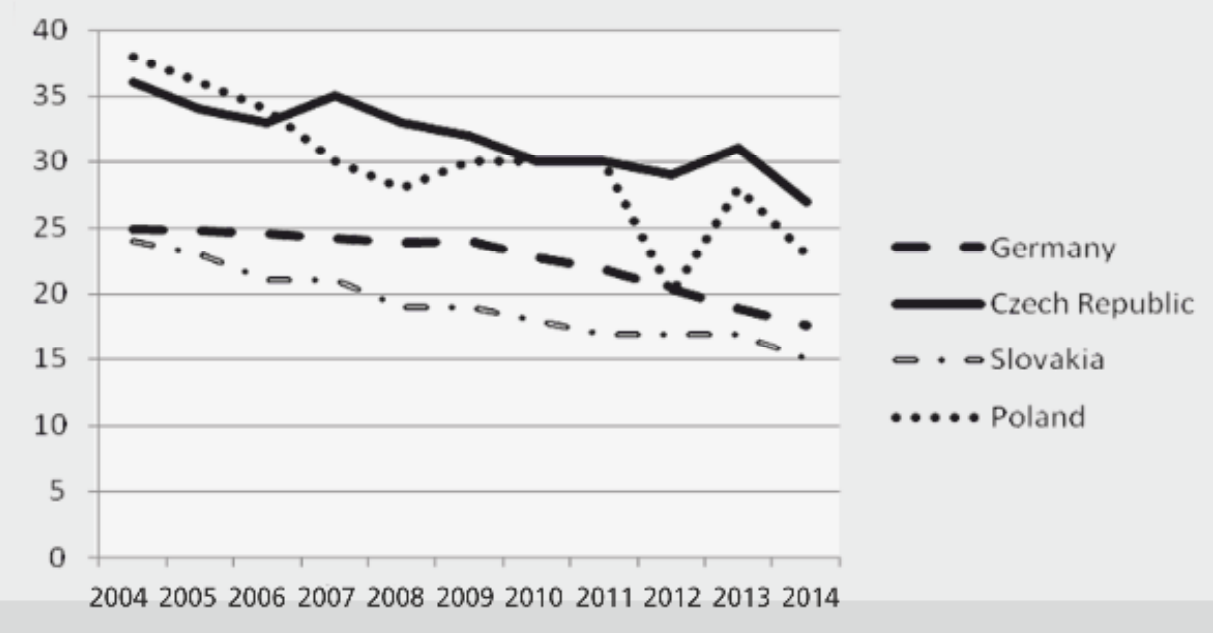

Figure 1. The level of crime recorded by the police in Poland ( $\cdots-$ ) and the average value of the index in Germany $(-4$, Czech Republic $(-)$, Slovakia $(\cdot-t)$ in 2004-2014 Source: own study based on EUROSTAT data

The analysis started with the presentation and comparison of data for Poland and the arithmetic average crime rate per 100000 inhabitants in selected EU 
countries in the period 2004-2014 (figure 1). For further considerations there were taken countries: Germany, Czech Republic, Slovakia, ie. our closest neighbors. On the basis of the collected data it can be stated that at the beginning of the twentyfirst century, the number of crimes recorded by the police per 1,000 inhabitants in Poland and the Czech Republic was at a similar level, ie. about 35 crimes per 1,000 residents. In contrast, in Germany and Slovakia, this level was lower and amounted to about 25 crimes per 1,000 residents. The years 2004-2014 in all countries in study brought a decline of this indicator in Germany and Slovakia to around 15, and in the Czech Republic and Poland to the level of 25 crimes per 1000 people. Generally, it is possible to notice that the declining trends of this index in selected countries are very similar, i.e. there was a decrease in crime by about $10 \%$.

The average value of crime rate in Poland in the years 2004-2014 amounted to 30.636 , and the number can be compared with the average crime rates in all police stations in the city and county of Walbrzych (Table 1). The area of the city and county of Walbrzych in 2010-2013 was covered by the Municipal Police (KMP), under which functioned: I Police Station (KP I), II Police Station (KP II), III Police Station (KP III), IV Police Station (KP IV), V Police Station (KP V) BoguszowGorce Police Station (KP B-G), Gluszyca Police Station (KP G), Mieroszow Police Station (KP M). In 2014, there was a reorganization of the structure of Municipal Police Headquarters. Due to functional and economic reasons in Walbrzych, there were combined areas of responsibility of some police stations. After the reorganization remained: I Police Station, II Police Station and V Police Station. The organization of Police structures in the county has not changed. On the basis of calculations it can be stated that the crime rate in II KP, III KP and V $\mathrm{KP}$ exceeded the average value of this indicator in Poland. This is important information for the evaluation of management of public security in those areas.

Table 2. The crimes recorded by the police in the police stations and an average absolute value and an average of the crime rate in 2004-2014

\begin{tabular}{c|c|c}
\hline Police Station & Average number of crimes & $\begin{array}{c}\text { Average value of crime rate per } \\
\mathbf{1 . 0 0 0} \text { residents }\end{array}$ \\
\hline KP I & 819,33 & 0,01795 \\
\hline KP II & $517,66 / 1087,83^{* *}$ & $0,02956^{*} / 0,03139^{* *}$ \\
\hline KP III & $354,33^{*}$ & $0,03263^{*}$ \\
\hline KP IV & $512,66,455^{*}$ & $0,022,36^{*}$ \\
\hline
\end{tabular}




\begin{tabular}{c|c|c} 
KP V & 561,83 & 0,03743 \\
\hline KP B-G & 402,17 & 0,01068 \\
\hline KP G & 327,33 & 0,01318 \\
\hline KP M & 119,40 & 0,01141 \\
\hline
\end{tabular}

Source: own calculations based on Listing of incidents occurring in KMP in Walbrzych 2004-2014 KMP Walbrzych. Comment: *data for 2004-2012;

**data for 2013-2014 after combining areas in KMP

In the cases of other police stations, the value of studied indicator was much lower than the national average. How did, then, the crime rate in the years 2004 - 2014 look like in particular police stations? A graphical presentation of the data was referred to in figure 2. On the basis of the evaluation it can be stated that the area of the city and county of Walbrzych is divided into parts significantly different in terms of the severity of the crime. Crime in II KP and V KP is much higher than in other areas of the studied area, and also higher than the national average. In the years 2004-2011 crime in IV KP was significantly lower than the national average.

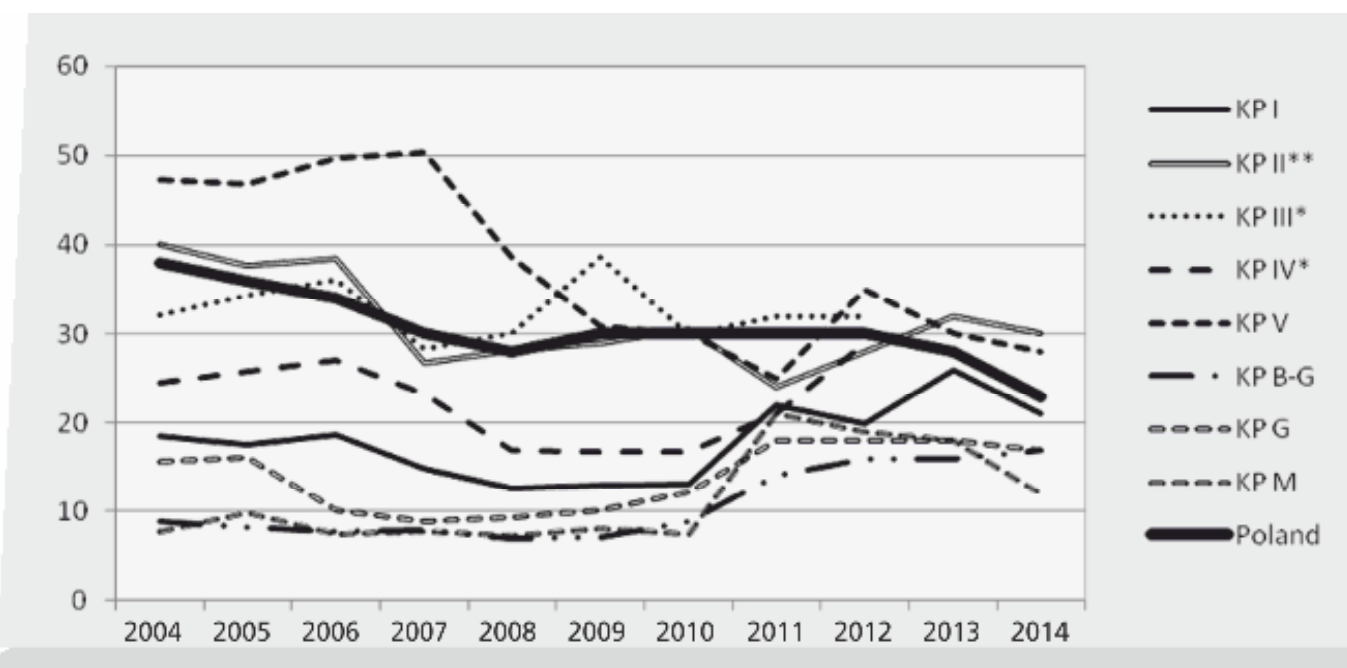

Figure 2. The crime rate recorded by KMP Walbrzych broken down at police stations in the years 2004-2014

Source: own calculations based on Listing of incidents occurring in KMP in Walbrzych 2004-2014 KMP Walbrzych. Comment: *data for 2004-2012;

**data for 2013-2014 after combining areas in KMP 
Only in 2012 crime in the area increased significantly, almost to the level of the national average. In the case of other police stations, the value of crime rate was lower than the national average in the considered period. The only exception is the area of responsibility of I Police Station, where since 2011 a systematic increase in the crime rate has been taking place, which in 2014 equated to the value of the national average. The area of responsibility of IV Police Station was special because it included essentially a densely populated downtown. Among other things, for this reason, since 2002 the implementation of a video monitoring system has begun. It is questionable whether the expected changes, i.e. reducing the level of crime because of the monitoring are visible in the coming years? In 2004-2006, despite the operation of the monitoring, there was a growth of the studied indicator. Next years, i.e. 2007-2009 brought a drop in crime rate, but in next three years, since 2010 there was an increase to the highest level $(29,1)$. It cannot therefore be concluded that the introduction of monitoring in the area of responsibility of IV Police Station had a significant impact on reducing the crime rate. Nevertheless, it is noteworthy that since the implementation of monitoring, the number of "common" crimes such as robbery, burglary and theft decreased.

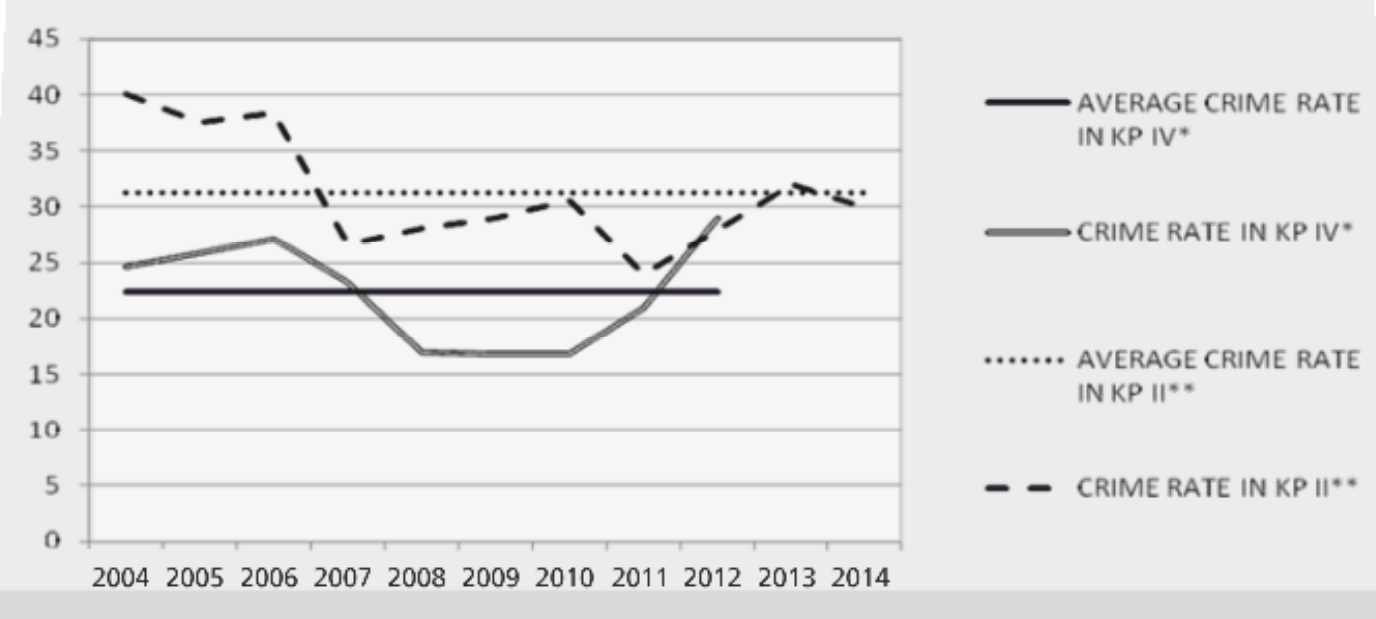

Figure 3. The average value of crime in relation to the crime rate in IV and $V$ police stations in KMP Walbrzych in the years 2004-2014

Source: own calculations based on Listing of incidents occurring in KMP in Walbrzych 2004-2014 KMP Walbrzych. Comment: *data for 2004-2012;

**data for 2013-2014 after combining areas in KMPP 


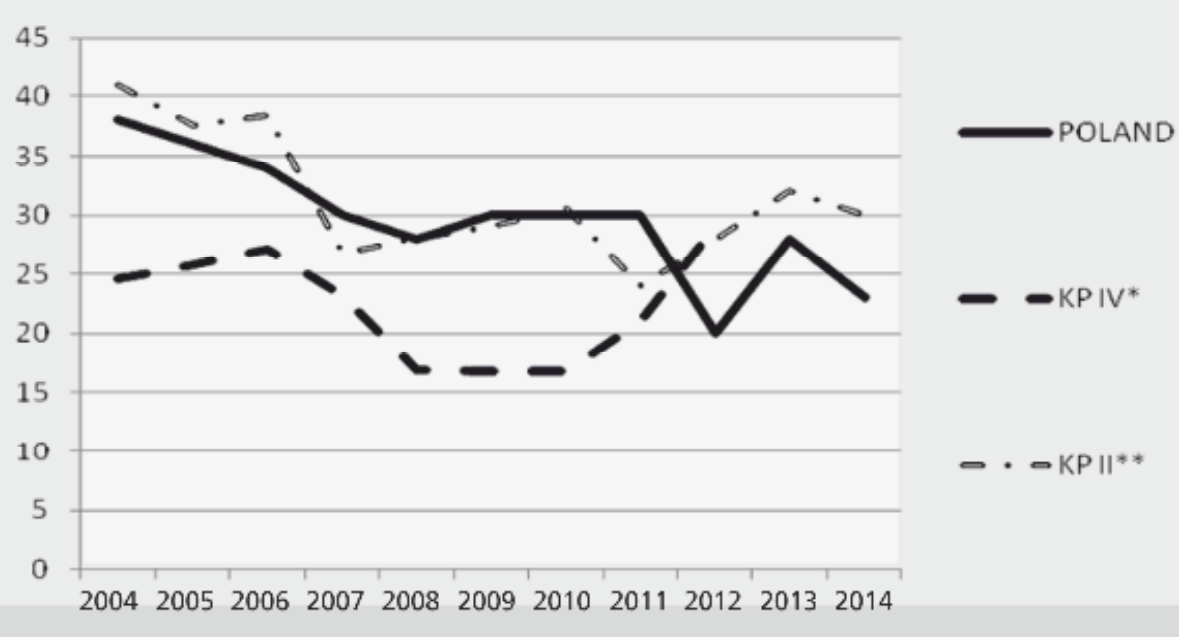

Figure 4. The level of crime recorded by IV and V police stations of KMP in Walbrzych and in Poland in the years 2004-2014

Source: own calculations based on Listing of incidents occurring in KMP in Walbrzych 2004-2014 KMP Walbrzych. Comment: *data for 2004-2012; $\star \star$ data for 2013-2014 after combining areas in KMP

There was especially a decrease of offenses particularly audacious committed in so-called "broad daylight". This is due to police reports of IV Police Station. Moreover, video monitoring influenced, despite the lack of statistically significant differences, the subjective sense of security of the local community living there.

It is also worth looking at the formation of the crime rate in the area of monitored police station in relation to the average value of this indicator in KP IV (until 2012) and later KP II (after the reorganization of the area of responsibility of KP IV - KP V took over) - figure 3. Although since the implementation of the first visual monitoring cameras in 2002, a slight increase occurred in two consecutive years, it is possible to talk about a good trend of studied phenomena until 2010.

It can prove that the effects of the implementation of monitoring may be postponed in time, which was examined in the next section. The crime rate in KP IV in relation to the value of this indicator in Poland in 2004-2010 was optimistic. Only in 2011-2012, there was a significant increase, above the national average. In the years 2013-2014 there was a further growth of the studied indicator (figure 4). The reason for this is probably the reorganization of the Police structure in Walbrzych and the resulting, especially in the initial phase of operation, problems. 
Table 3. The dynamics of the crime rate recorded by the police in Police Stations in 2004-2014

\begin{tabular}{c|c|c|c|c|c|c|c|c}
\hline \multirow{2}{*}{ years } & \multicolumn{7}{|c}{ Police Station } \\
\cline { 2 - 9 } & KP I & KP II & KP III* & KP IV* & KP V & KP B-G & KP G & KP M \\
\hline 2004 & 108,25 & 120,38 & 100,00 & $\mathbf{1 0 7 , 3 6}$ & 119,71 & 115,05 & 95,10 & 67,65 \\
\hline 2005 & 94,15 & 91,36 & 110,05 & $\mathbf{1 0 2 , 4 1}$ & 97,71 & 88,19 & 101,37 & 137,68 \\
\hline 2006 & 104,94 & 106,37 & 102,90 & $\mathbf{1 0 5 , 3 3}$ & 110,14 & 88,04 & 69,15 & 61,05 \\
\hline 2007 & 77,03 & 65,52 & 78,63 & $\mathbf{8 3 , 6 5}$ & 102,27 & 101,09 & 73,04 & 118,97 \\
\hline 2008 & 80,93 & 102,77 & 107,69 & $\mathbf{6 8 , 7 8}$ & 74,38 & 85,48 & 118,79 & 91,30 \\
\hline 2009 & 98,05 & 105,66 & 128,57 & $\mathbf{9 8 , 7 7}$ & 81,75 & 102,52 & 115,82 & 112,70 \\
\hline 2010 & 111,42 & 113,27 & 76,67 & $\mathbf{1 0 0 , 4 1}$ & 98,18 & 111,66 & 128,29 & 90,14 \\
\hline 2011 & 91,20 & 100,80 & 106,20 & $\mathbf{9 4 , 1 0}$ & 101,60 & 118,41 & 118,61 & 146,11 \\
\hline 2012 & 92,70 & 117,51 & 100,30 & $\mathbf{1 3 7 , 1 1}$ & 140,81 & 117,50 & 89,31 & 101,11 \\
\hline 2013 & 128,8 & $\mathbf{1 0 8 , 8 1 * *}$ & - & - & 85,11 & 96,40 & 98,61 & 94,70 \\
\hline 2014 & 82,71 & $\mathbf{9 3 , 6 0 * *}$ & - & - & 94,00 & 21,80 & 95,61 & 69,00 \\
\hline
\end{tabular}

Source: own calculations based on Listing of incidents occurring in KMP in Walbrzych 2004-2014 KMP Walbrzych. Comment: *data for 2004-2012; **data for 2013-2014 after combining areas in KMP

In addition, it is worth analysing the dynamics of the examined phenomenon in all police stations in the city and county of Walbrzych (table 2). Calculations for IV/V police stations, where in the area of responsibility the monitoring system operates, were indicated in bold. The dynamics was calculated by the indexation of the chain, i.e. in comparison to the previous year.

From table 2 it can be stated that in the case of KP IV after 2004 (i.e. already in the period of city monitoring operation), the values of the crime rate decreased until 2010. In 2010 and 2012, it is possible to notice that the effects of the introduction of monitoring, despite its further development - are poorly visible. Only the years 2013-2014 brought a marked improvement. This could be due to, among other things, the installation of up to 21 cameras in the city centre.

However, it can be assumed, which however requires further studies, that the negative result of the implementation of video monitoring systems in Walbrzych 
and other towns of the county is an increase in crime in the areas surrounding the monitored sites, for example, the area of KP V, KP B-G and KP G.

\section{Conclusions}

On the basis of conducted studies it cannot be clearly stated that the video monitoring system in Walbrzych contributed significantly to the decrease in crime in the monitored areas. This is due to the fact that the level of crime within any area is determined by many factors, and video monitoring only one of them.The result of past performance of the city monitoring is the growth of a subjective sense of security of the local community. According to the police, due to monitoring the detection of crimes and criminals increased by allowing the use of recorded material for legal purposes. It should be emphasized that the strength of video monitoring is its prevention impact. However, in order to trigger an increase in the effects of video monitoring systems, according to the author, the introduction of a number of best practices should be necessary, which would result in expected effects. The most important solutions should include:

- increasing the number of operating staff of visual monitoring systems,

- introducing monitoring operators, and so the change from the reactive systems - into proactive,

- increasing the quantity and quality of cameras in monitoring systems in agreement of their location with local communities and local structures of the Police,

- considering the possibility of combining monitoring call centres with the positions of control of the Police, the Municipal Guards with visual links. It would enable a real-time preview of selected event for dispatchers of these positions, and thus a faster response to changes. Such a solution has existed for many years in Białystok.

\section{Summary}

Management of public safety with the use of visual monitoring in the city and county of Walbrzych

The paper presents basic legal conditions related to the operation and types of video monitoring systems. These considerations include the attempt to diagnose the impact of the use of video monitoring systems on the number of new cases initiated on the basis of the crime rate in the area of the city and county of 
Walbrzych. The article contains a comparative study based on this indicator in the studied area, in Poland and the EU countries.

Key words: safety of local communities, visual monitoring, statistical data.

\section{Streszczenie}

Zarządzanie bezpieczeństwem publicznym $\mathrm{z}$ wykorzystaniem monitoringu wizyjnego na przykładzie miasta i powiatu wałbrzyskiego

Artykuł ukazuje podstawowe uwarunkowania prawne związane z funkcjonowaniem i rodzajami systemów monitoringu wizyjnego. Niniejsze rozważania zawierają próbę diagnozy wpływu stosowania systemów monitoringu wizyjnego na liczbę wszczętych postępowań w oparciu o wskaźnik zagrożenia przestępczością na obszarze miasta i powiatu wałbrzyskiego. Artykuł zawiera badanie komparatystyczne $\mathrm{w}$ oparciu o ten wskaźnik w badanym obszarze, Polsce oraz krajach UE.

\section{Słowa}

kluczowe: bezpieczeństwo społeczności lokalnych, monitoring wizyjny, dane statystyczne.

\section{References:}

1. Fudala A., Piniewicz D. (2015), Monitoring wizyjny: obowiazki sa, ustawy nie ma, http:// ictprofessional.pl/monitoring-wizyjnyobowiazki-sa-ustawynie-ma/(15.01.2016 r. - access date).

2. Główny Urząd Statystyczny, (2014), Bank danych lokalnych, Warszawa.

3. Gołębiowski P. (2010), Walbrzych: Nowe kamery w mieście, "Gazeta Wrocławska", 14.06.2010, Wrocław.

4. http://www.strazmiejskawalbrzych.pl.

5. http://www.strazmiejskajaslo.pl/index.php/monitoring-wizyjny (15.01.2016 r. - access date).

6. Monitoring wizyjny Walbrzycha (2016) http://strazmiejska.walbrzych. $\mathrm{pl}$ /index.php/ informator/158-monitoring (15.01.2016 r. - access date).

7. PN-EN 50132-7:2003, Systemy alarmowe - Systemy dozorowe CCTV stosowane w zabezpieczeniach - Part VII: Wytyczne stosowania, 2003, Warszawa.

8. Raport Najwyższej Izby Kontroli (2013), Funkcjonowanie miejskiego monitoringu wizyjnego, Warszawa. (LLU - 4101-01-00/2013 Nr ewid. 181/2013/P/13/154). 
9. Sienkiewicz-Małyjurek K. Niczyporuk Z. 2010, Bezpieczeństwo publiczne. Zarys problemu, Wydawnictwo Politechniki Śląskiej, Gliwice.

10. Sienkiewicz-Małyjurek K. (2010), Organizacja a efektywność systemów monitoringu wizyjnego, [in:] W. Fehler (ed.) Bezpieczeństwo publiczne w przestrzeni miejskiej, Arte, Biała Podlaska.

11. Skórzyńska-Ślusarek J. (2013), Monitoring wizyjny w życiu społecznym. Raport z badań Fundacja Panoptykon, Fundacja Projekt, Warszawa.

Wikariak S. (2014), Kamery dziataja nielegalnie. Monitoring wizyjny wciąż nieuregulowany, http:// prawo. gazetaprawna.pl artykuly/831753, kamery-dzialaja-nielegalnie-monitoring-wizyjny-wciaz-nieuregulowany. html (28.10.2014 r. - access date).

12. Ustawa o Policji, (Dz.U. 2007r. nr 43, poz. 277 z późn. zm.).

13. Ustawa o ochronie osób i mienia (Dz.U. 1997.114.740 z późn. zm.).

14. Ustawa o bezpieczeństwie imprez masowych (Dz. U. z 2009.62. 504 z późn. zm.).

15. Ustawa o zarządzaniu kryzysowym (Dz.U. z 2007.89.590 z późn. zm.).

16. Ustawa o strażach gminnych (Dz.U. 1997.123.779 z późn. zm.).

17. Ustawa o ochronie danych osobowych (Dz.U. 1997.133. 883 z późn. zm.).

18. Ustawa kodeks postępowania karnego (Dz. U. z 1997.89.555 z późn. zm.).

19. Ustawa kodeks karny wykonawczy (Dz. U. z 1997.90.557 z późn. zm.).

20. Ustawa o grach hazardowych (Dz. U. z 2009.201.1540 z późn. zm.).

21. Wykaz kamer działających w systemie monitoringu wizyjnego miasta Wałbrzycha (2015), Urząd Miasta Wałbrzych.

22. Zestawienia zdarzeń zaistniatych na terenie KMP w Wałbrzychu 2004-2014 (2015) KMP Wałbrzych. 